\title{
PENGARUH PROFITABILITAS, LEVERAGE DAN UKURAN PERUSAHAAN TERHADAP LAMA WAKTU LAPORAN AUDIT
}

\author{
Syifa Tamara Putri \\ Universitas Pembangunan Nasional "Veteran" Jakarta \\ syifatamaratp@gmail.com \\ Samin \\ Universitas Pembangunan Nasional "Veteran" Jakarta \\ samin58@ymail.com
}

\begin{abstract}
This study aims to test and provide empirical the effect of profitability, leverage and firm size of the audit report lag. The population in this study is a sub company property and real estate sectors listed on the Indonesia Stock Exchange 2012-2014. Sample of 34 companies was selected by purposive sampling method. The data used in this study as much as 102 samples. This study uses several stage of calculation, using outlier test that is by converting the data into a standardized score or so-called z-score. After going through the process of outlier samples were chosen in this study to 93 samples. Analysis of the data using multiple linear regression with a significance level of 5\% and determine the hypothesis used t test and f test. The results test showing that profitability, leverage and firm size are simultaneous positive and significant effect on audit report lag. The results test this study indicate that profitability has significance on audit report lag are partial. Meanwhile leverage and firm size has no significance on audit report lag.
\end{abstract}

Keywords: Profitability, Leverage, Firm Size, Audit Report Lag.

\section{PENDAHULUAN}

\subsection{Latar Belakang Penelitian}

Laporan keuangan merupakan salah satu instumen penting dalam mendukung keberlangsungan suatu perusahaan, terutama perusahaan yang telah go public. Seiring dengan pesatnya perkembangan perusahaan-perusahaan yang go public, semakin tinggi pula permintaan atas audit laporan keuangan yang menjadi sumber informasi bagi investor. Informasi dalam laporan keuangan tersebut akan bermanfaat jika disajikan sesuai standar yang berlaku dan tentunya harus tepat waktu. Dalam rangka pemberian informasi yang akurat kepada pengguna laporan keuangan mengenai kondisi keuangan emiten atau perusahaan publik di Indonesia, setiap perusahaan yang go public diwajibkan untuk menyampaikan laporan keuangan yang disusun sesuai dengan Standar Akuntansi Keuangan (SAK) dan telah diaudit oleh akuntan publik (Togasima \& Christiawan 2010).

Audit Report Lag adalah panjangnya waktu akhir tahun fiskal suatu perusahaan dengan tanggal yang tertera dalam laporan audit. Audit Report Lag menunjukkan rentang penyelesaian audit, dengan tujuan menyeluruh dari laporan audit keuangan yaitu menyatakan pendapat akan laporan keuangan yang disajikan secara wajar dalam semua hal yang sesuai dengan prinsip akuntansi yang berlaku umum. Ketepatan waktu perusahaan dalam mempublikasikan laporan keuangan kepada umum tergantung dari ketepatan waktu auditor dalam menyelesaikan pekerjaan auditnya (Togasima \& Christiawan 2010). Berikut ini adalah tabel fenomena audit report lag yang terjadi pada perusahaan yang terlambat dalam menyampaikan laporan keuangan tahun 2013: 
Tabel 1 Fenomena Audit Report Lag

\begin{tabular}{|c|c|c|c|c|c|}
\hline No & $\begin{array}{c}\text { Kode } \\
\text { Perusahaan }\end{array}$ & Variabel & Tahun & Nilai & $\begin{array}{c}\text { Audit Report } \\
\text { Lag (Hari) }\end{array}$ \\
\hline \multirow{2}{*}{1} & \multirow{2}{*}{ MTFN } & \multirow{2}{*}{ Profitabilitas } & 2012 & $-4,96 \%$ & 95 \\
\hline & & & 2013 & $25,67 \%$ & 127 \\
\hline \multirow{2}{*}{2} & \multirow{2}{*}{ MAGP } & \multirow{2}{*}{ Leverage } & 2012 & $80,61 \%$ & 73 \\
\hline & & & 2013 & $30,32 \%$ & 148 \\
\hline 3 & ELTY & Ukuran Perusahaan & 2013 & Rp 12,3 Trilyun & 153 \\
\hline
\end{tabular}

Sumber: Data hasil olahan

Berdasarkan tabel 1 di atas, diketahui bahwa PT. Capitalinc Investment Tbk. (MTFN) mengalami profitabilitas yang naik, tahun 2012 mengalami kerugian sebesar 4,96\% dengan audit report lag selama 95 hari serta tanggal laporan audit pada 5 April 2013 sementara tahun 2013 mengalami keuntungan sebesar 25,67\% dengan audit report lag selama 127 hari serta tanggal laporan audit pada 7 Mei 2014. Seharusnya perusahaan yang mengalami keuntungan memiliki audit report lag yang pendek/cepat sehingga perusahaan tidak terlambat dalam menyampaikan laporan keuangan, sedangkan perusahaan yang mengalami kerugian memiliki audit report lag yang panjang.

PT. Multi Agro Gemilang Plantation Tbk. (MAGP) mengalami penurunan leverage, tahun 2012 sebesar 80,61\% dengan audit report lag selama 73 hari dan tanggal laporan audit pada 14 Maret 2013 sementara tahun 2013 leverage sebesar 30,32\% dengan audit report lag selama 148 hari dan tanggal laporan audit pada 28 Mei 2014. Seharusnya perusahaan yang memiliki leverage tinggi, audit report lag-nya lebih panjang/lama, sedangkan perusahaan yang memiliki leverage rendah, audit report lag-nya akan lebih pendek/cepat.

PT. Bakrieland Development Tbk. (ELTY) tahun 2013 memiliki total aset Rp 12.301.124.419.066 atau lebih dari Rp 100.000.000.000 (seratus miliar rupiah) yang merupakan kategori perusahaan besar, seharusnya audit report lag perusahaan dapat lebih pendek/cepat dan terhindar dari keterlambatan penyampaian laporan keuangan. Faktanya, audit report lag PT. Bakrieland Development Tbk. sebesar 153 hari dengan tanggal laporan audit 2 Juni 2014, akibatnya PT. Bakrieland Development Tbk. terlambat dalam menyampaikan laporan keuangan. Perusahaan besar semestinya memiliki sistem pengendalian internal yang memadai serta pengawasan dari pihak-pihak eksternal sehingga memudahkan dalam proses audit, sehingga audit report lag perusahaan akan lebih cepat/pendek.

Berdasarkan fenomena tersebut menunjukkan bahwa sampai saat ini masih banyak perusahaan go public yang mengalami audit report lag panjang/lama, yang mengakibatkan perusahaan terlambat dalam menyampaikan laporan keuangan. Seharusnya berdasarkan Keputusan Ketua Badan Pengawas Pasar Modal (BAPEPAM) dan Lembaga Keuangan (LK) Nomor: KEP-346/BL-2011 mewajibakan setiap emiten dan perusahaan publik yang terdaftar di Bursa Efek Indonesia untuk menyampaikan laporan keuangan tahunan disertai dengan laporan akuntan dalam rangka audit atas laporan keuangan yang memuat opini audit dari akuntan kepada BAPEPAM dan LK paling lama 3 bulan (90 hari) setelah tanggal laporan keuangan tahunan. Pada 1 Agustus 2012 BAPEPAM dan LK mengeluarkan peraturan XK 6 pada Lampiran Nomor: Kep-431/BL/2012 yang menyatakan bahwa emiten atau perusahaan publik yang pernyataan pendaftarannya telah menjadi efektif wajib menyampaikan laporan keuangan dan laporan akuntan kepada BAPEPAM dan LK paling lama 4 (empat) bulan (120 hari) setelah tahun buku berakhir. BAPEPAM kini diganti menjadi Otoritas Jasa Keuangan (OJK) yang berperan sebagai pengawas dan pembuat kebijakan di Pasar Modal. OJK dibentuk berdasarkan UU Nomor 21 Tahun 2011 dan mulai berdiri menggantikan BAPEPAM pada 1 Januari 2013.

(OJK, 2014) 


\section{TINJAUAN PUSTAKA DAN HIPOTESIS}

\subsection{Teori Keagenan}

Teori keagenan menyebutkan bahwa perusahaan adalah tempat atau intersection point bagi hubungan kontrak yang terjadi antara manajemen, pemilik, kreditor, dan pemerintah. Teori ini bercerita tentang monitoring berbagai macam biaya dan memaksakan hubungan diantara kelompok ini. Audit dianggap sebagai alat meyakinkan diri bahwa laporan keuangan harus tergantung pada pemeriksaan dari aspek pengawasan intern. Seandainya laporan hasil pemeriksaan akuntan adalah wajar, ini berarti bahwa penyajiannya telah sesuai dengan prinsip akuntansi. Dalam hal ini, audit memberikan keyakinan kepada pihak luar, pemilik, dan kreditor tentang pengelolaan perusahaan oleh manajemen sebagai agen (Harahap 2011, hlm.532)

Febrianty (2011) menyatakan bahwa indikasi audit report lag bagi pihak perusahaan emiten adalah diperlukannya biaya agensi untuk mengembalikan kepercayaaan investor seperti biaya untuk pengungkapan informasi tambahan, kaitannya adalah semakin panjang audit report lag dan semakin sering audit report lag terjadi maka akan semakin besar pula biaya agensi yang harus dikeluarkan.

\subsection{Audit Report Lag}

Arens et.al (2008, hlm.58) menyatakan bahwa 'laporan audit (audit report) adalah tahap akhir dari keseluruhan proses audit'. Laporan audit baku terdiri dari tiga paragraf : paragraf pengantar (introductory paragraph), paragraf lingkup (scope paragraph), dan paragraf pendapat (opinion paragraph).

Menurut Hersugondo \& Kartika (2012) audit report lag merupakan lamanya/rentang waktu penyelesaian audit yang diukur dari tanggal penutupan tahun buku sampai dengan tanggal diterbitkannya laporan audit. Audit report lag inilah yang dapat mempengaruhi ketepatan informasi yang dipublikasikan, sehingga akan berpengaruh terhadap tingkat ketidakpastian keputusan yang berdasarkan informasi yang dipublikasikan. Audit report lag diukur dari selisih hari antara tanggal ditandatanganinya laporan auditor independen dengan tanggal tutup buku laporan keuangan tahunan.

\subsection{Pengaruh Profitabilitas Terhadap Audit Report Lag}

Sudana (2011, hlm.22) berpendapat bahwa 'profitabilitas adalah kemampuan perusahaan untuk menghasilkan laba dengan menggunakan sumber-sumber yang dimiliki perusahaan, seperti aktiva, modal, atau penjualan perusahaan'.

Carslaw \& Kaplan dalam Hersugondo \& Kartika (2013) menyatakan bahwa 'perusahaan yang mengalami kerugian, audit report lag perusahaan tersebut akan lebih panjang/lama. Karena auditor akan lebih berhati-hati selama proses audit jika percaya bahwa profitabilitas yang rendah atau kerugian mungkin disebabkan karena kegagalan keuangan perusahaan dan kecurangan manajemen informasi tentang laba, dimana auditor akan menyampaikan bad news kepada investor dan pihak-pihak lainnya. Sebaliknya jika perusahaan mengalami keuntungan, audit report lag akan lebih pendek/cepat, sehingga good news tersebut dapat segera disampaikan kepada investor dan pihak-pihak lainnya'. Dengan kata lain perusahaan yang memiliki profitabilitas rendah, audit report lag-nya akan lebih lama dibanding perusahaan yang memiliki profitabilitas tinggi. Karena perusahaan yang memiliki profitabilitas rendah akan membawa dampak buruk yang menyebabkan turunnya penilaian kinerja suatu perusahaan.

Ariyani dan Budiartha (2014) menyatakan profitabilitas berpengaruh signifikan terhadap audit report lag. Hasil penelitian Vuko dan Cular (2014) juga menyatakan profitabilitas berpengaruh signifikan terhadap audit report lag.

Berdasarkan penjelasan di atas mengenai pengaruh profitabilitas terhadap audit report lag, dapat disusun hipotesis penelitian sebagai berikut:

$\mathbf{H}_{1}$ : Profitabilitas berpengaruh signifikan terhadap audit report lag 


\subsection{Pengaruh Leverage Terhadap Audit Report Lag}

Leverage merupakan kemampuan suatu perusahaan untuk membayar semua hutanghutangnya baik jangka pendek maupun jangka panjang.

Weston \& Copeland dalam Hersugondo \& Kartika (2013) menyatakan semakin tinggi tingkat leverage perusahaan mencerminkan semakin tingginya risiko perusahaan. Risiko perusahaan yang tinggi mengindikasikan bahwa perusahaan mengalami kesulitan keuangan. Kesulitan keuangan merupakan berita buruk (bad news) yang akan mempengaruhi kondisi perusahaan di mata masyarakat. Pihak manajemen cenderung menunda penyampaian berita buruk (bad news) perusahaan kepada investor dan pihak-pihak lainnya. Dengan kata lain, perusahaan yang memiliki leverage tinggi, audit report lag-nya lebih lama. Sedangkan perusahaan yang memiliki leverage rendah, audit report lag-nya lebih cepat/pendek.

Angruningrum \& Wirakusuma (2013) menyatakan bahwa leverage yang diproksikan dengan Debt to Equity Ratio (DER) berpengaruh signifikan terhadap audit report lag. Hasil penelitian yang dilakukan oleh Vuko \& Cular (2014) juga menyatakan bahwa leverage berpengaruh signifikan terhadap audit report lag.

Berdasarkan penjelasan di atas mengenai pengaruh leverage terhadap audit report lag, dapat disusun hipotesis penelitian sebagai berikut:

$\mathbf{H}_{2}$ : Leverage berpengaruh signifikan terhadap audit report lag

\subsection{Pengaruh Ukuran Perusahaan Terhadap Audit Report Lag}

Ukuran perusahaan adalah besar kecilnya suatu perusahaan yang diukur dari besarnya total aset atau kekayaan yang dimiliki oleh suatu perusahaan' (Febrianty, 2011). Dyer \& Mc Hugh dalam Hersugondo \& Kartika (2013) menyatakan bahwa 'perusahaan besar lebih konsisten untuk tepat waktu dibandingkan dengan perusahaan kecil dalam menginformasikan laporan keuangannya. Pengaruh ini ditunjukkan dengan semakin besar nilai aset perusahaan, semakin pendek audit report lag-nya'. Perusahaan besar diduga akan menyelesaikan proses auditnya lebih cepat dibandingkan perusahaan kecil. Hal ini disebabkan oleh beberapa faktor yaitu manajemen perusahaan yang berskala besar cenderung diberikan insentif untuk mengurangi audit report lag, dikarenakan perusahaan tersebut dimonitor secara ketat oleh investor dan pengawas permodalan dari pemerintah. Sehingga kategori ukuran perusahaan besar yang dilihat dari nilai aset perusahaan, audit report lag-nya akan lebih pendek dibandingkan dengan perusahaan kategori ukuran perusahaan kecil, yang audit report lag-nya akan lebih lama/panjang.

Febrianty (2011) menyatakan bahwa ukuran perusahaan berpengaruh signifikan terhadap audit report lag. Hasil penelitian yang dilakukan oleh Puspitasari \& Sari (2012) juga menyatakan bahwa ukuran perusahaan berpengaruh signifikan terhadap audit report lag.

Berdasarkan penjelasan di atas mengenai pengaruh ukuran perusahaan terhadap audit report lag, dapat disusun hipotesis penelitian sebagai berikut:

$\mathbf{H}_{3}$ : Ukuran Perusahaan berpengaruh signifikan terhadap audit report lag

\section{METODE PENELITIAN}

\subsection{Definisi Operasional dan Pengukuran Variabel}

Variabel dependen dalam penelitian ini adalah audit report lag. Audit report lag adalah lamanya/rentang waktu penyelesaian audit dari tanggal penutupan tahun buku sampai dengan tanggal diterbitkannya laporan audit (Hersugondo \& Kartika 2013). Audit Report Lag (Y) diukur dengan selisih hari antara tanggal ditandatanganinya laporan auditor independen dengan tanggal tutup buku laporan keuangan tahunan.

Variabel independen terdiri dari :

a. Profitabilitas $\left(\mathrm{X}_{1}\right)$

Profitabilitas merupakan kemampuan perusahaan untuk menghasilkan laba dengan menggunakan sumber-sumber yang dimiliki perusahaan, seperti aktiva, modal, atau penjualan perusahaan menilai kemampuan perusahaan dalam mencari keuntungan (Sudana, 
$2011 \mathrm{hlm.22).} \mathrm{Variabel} \mathrm{profitabilitas} \mathrm{dalam} \mathrm{penelitian} \mathrm{ini} \mathrm{diukur} \mathrm{dengan} \mathrm{skala} \mathrm{rasio} \mathrm{dengan}$ menggunakan Return on Assets (ROA) dengan rumus:

$$
\mathrm{ROA}=\frac{\text { Earning After Taxes }}{\text { Total Assets }}
$$

b. Leverage $\left(\mathrm{X}_{2}\right)$

Leverage menggambarkan seberapa jauh perusahaan dibiayai oleh utang, artinya besarnya jumlah utang yang digunakan perusahaan untuk membiayai kegiatan usahanya jika dibandingkan dengan menggunakan equity (Harahap 2013, hlm.306). Variabel leverage dalam penelitian ini diproksikan dengan Debt to Equity Ratio (DER) menggunakan rumus :

$$
\begin{aligned}
\text { DER } & =\frac{\text { Total Liabilities }}{\text { Total Equity }} \\
\text { ROA } & =\frac{\text { Earning After Taxes }}{\text { Total Assets }}
\end{aligned}
$$

c. Ukuran Perusahaan $\left(\mathrm{X}_{3}\right)$

Ukuran perusahaan adalah besar kecilnya suatu perusahaan. Indikator besar kecilnya suatu perusahaan ditentukan berdasarkan total aset atau kekayaan yang dimiliki oleh suatu perusahaan (Febrianty 2011). Variabel ukuran perusahaan dapat diukur dengan total assets yang dimiliki perusahaan yang diproksikan dengan logaritma, dengan rumus:

Ukuran Perusahaan $=$ Ln Total Assets

\subsection{Populasi dan Sampel}

Objek penelitian yang digunakan adalah perusahaan sub sektor property dan real estate yang terdaftar di Bursa Efek Indonesia (BEI) selama tahun 2012-2014. Jumlah populasi sebanyak 45 perusahaan, penentuan sampel berdasarkan kriteria tertentu (purposive sampling). Kriteria sampel dalam penelitian ini adalah sebagai berikut:

a. Perusahaan sub sektor property dan real estate yang terdaftar di BEI secara berturut-turut tahun 2012-2014

b. Perusahaan yang menerbitkan laporan keuangan yang telah diaudit dan dipublikasikan secara berturut-turut pada periode tahun 2012-2014.

c. Perusahaan yang memperoleh laba secara berturut-turut tahun 2012-2014

\section{HASIL PENELITIAN DAN PEMBAHASAN}

\subsection{Analisis Data}

Statistik deskriptif memberikan gambaran atau deskripsi suatu data yang dilihat dari nilai rata-rata (mean), standar deviasi, maksimum dan minimum. Berikut ini tabel hasil uji statistik deskriptif sebelum outlier:

Tabel 2 Hasil Uji Statistik Deskriptif Sebelum Outlier

\begin{tabular}{lccccc}
\hline & $\mathrm{N}$ & Minimum & Maximum & Mean & $\begin{array}{c}\text { Std. } \\
\text { Deviation }\end{array}$ \\
\hline Audit Report Lag & 102 & 40 & 99 & 77,64 & 9,831 \\
Profitabilitas & 102 &, 41 & 31,61 & 7,3425 & 5,43642 \\
Leverage & 102 & 13,98 & 284,94 & 81,8535 & 50,85668 \\
Ukuran Perusahaan & 102 & 25,79 & 31,26 & 28,8991 & 1,20300 \\
Valid N (listwise) & 102 & & & & \\
\hline \multicolumn{1}{l}{ Sumber: }
\end{tabular}

Sumber: data sekunder yang telah diolah 
Berdasarkan tabel 2, dapat diketahui bahwa jumlah sampel yang digunakan dalam penelitian ini adalah 102 sampel. Nilai rata-rata (mean) audit report lag yang terjadi di perusahaan sub sektor property dan real estate yang terdaftar di Bursa Efek Indonesia (BEI) pada tahun 2012-2014 adalah sebesar 77,64 hari yang artinya perusahaan sub sektor property dan real estate yang terdaftar di Bursa Efek Indonesia (BEI) pada tahun 2012-2014 memiliki audit report lag yang cepat/pendek karena kurang dari 90 hari. Standar deviasi sebesar 9,831 menunjukkan bahwa data mengelompok disekitar rata-rata, karena nilai rata-rata (mean) lebih besar dari nilai standar deviasi. Nilai minimum audit report lag sebesar 40 hari, yang dimiliki PT. Duta Pertiwi Tbk. (DUTI) tahun 2014 dengan tanggal laporan audit pada 9 Februari 2015 artinya PT. Duta Pertiwi Tbk. tahun 2014 memiliki audit report lag yang cepat/pendek, karena audit report lag-nya kurang dari 90 hari. Sedangkan nilai maksimum audit report lag sebesar 99 hari, yang dimiliki oleh PT. Perdana Gapura Prima Tbk. (GPRA) tahun 2014 dengan tanggal laporan audit pada 9 April 2015 artinya PT. Perdana Gapura Prima Tbk. tahun 2014 memiliki audit report lag yang lama/panjang, karena audit report lag-nya lebih dari 90 hari.

Variabel profitabilitas memiliki nilai rata-rata (mean) 7,3425\% artinya total aset perusahaan sub sektor property dan real estate yang terdaftar di Bursa Efek Indonesia (BEI) pada tahun 2012-2014 dapat menghasilkan profitabilitas sebesar 7,3425\%. Nilai standar deviasi 5,43642 menunjukkan bahwa data mengelompok disekitar rata-rata, karena nilai rata-rata lebih besar dari nilai standar deviasi. Nilai minimum sebesar $0,41 \%$ dimiliki oleh PT. Sentul City Tbk. (BKSL) tahun 2014 artinya perusahaan berada dalam kondisi yang kurang baik karena tidak mampu menghasilkan laba yang maksimal, dimana aset sebesar Rp 9.796.065.262.250 hanya mampu menghasilkan laba bersih setelah pajak sebesar Rp 40.727.292.707 dan nilai maksimum sebesar 31,61\% yang dimiliki oleh PT. Dadanayasa Arthatama Tbk. (SCBD) tahun 2013. Nilai maksimum ini menunjukan kemampuan perusahaan dalam menghasilkan laba cukup baik, dimana aset sebesar Rp 5.550.429.288.000 mampu menghasilkan laba bersih setelah pajak sebesar $\mathrm{Rp}$ 1.754.524.211.000 dan mampu memberikan dampak yang positif dalam meningkatkan kepercayaan investor dalm menginvestasikan sahamnya pada perusahaan.

Variabel leverage memiliki nilai rata-rata (mean) $81,8535 \%$ artinya liabilitas sebesar $81,8535 \%$ diperoleh melalui ekuitas dari perusahaan sub sektor property dan real estate yang terdaftar di Bursa Efek Indonesia (BEI) pada tahun 2012-2014. Standar deviasi 50,85668 menunjukkan bahwa data mengelompok disekitar rata-rata, karena nilai rata-rata (mean) lebih besar dari nilai standar deviasi. Nilai minimum sebesar 13,98\% yang dimiliki oleh PT. Grennwood Sejahtera Tbk. (GWSA) tahun 2013 dimana total hutang sebesar Rp 250.934.436.830 lebih kecil dibanding total ekuitasnya sebesar Rp 1.794.767.347.615. Hasil ini menunjukkan bahwa leverage PT. Grennwood Sejahtera Tbk. tahun 2013 termasuk baik, karena liabilitas yang dimiliki perusahaan tidak tinggi sehingga risiko keuangan perusahaan cukup rendah. Hal ini memberikan dampak positif bagi perusahaan untuk meningkatkan kepercayaan investor. Sedangkan nilai maksimum sebesar 284,94\% yang dimiliki oleh PT. Goa Makassar Tourism Tbk. (GMTD) tahun 2012, dimana total hutang sebesar Rp 666.641.585.555 lebih besar dari total ekuitas yang dimiliki yaitu sebesar Rp 233.955.480.761. Hal ini menujukkan bahwa tingkat leverage yang dimiliki oleh PT. Goa Makassar Tourism Tbk. tahun 2012 kurang baik, karena sumber dana yang diperlukan lebih besar sehingga risiko keuangan yang dimiliki perusahaan akan cenderung besar pula, hal ini dikhawatirkan akan membuat para investor merasa ragu untuk menanamkan modal mereka kedalam perusahaan karena tingkat risiko perusahaan cenderung tinggi.

Variabel ukuran perusahaan nilai rata-rata (mean) 28,8991 dan standar deviasi 1,20300 menunjukkan bahwa data mengelompok disekitar rataan, karena nilai rata-rata (mean) lebih besar dari nilai standar deviasi. Nilai minimum sebesar 25,79 atau sebesar Rp 159.093.151.873 termasuk kategori ukuran perusahaan besar karena memiliki total aset lebih dari Rp 100.000.000.000 yang dimiliki oleh PT. Bekasi Asri Pemula Tbk. (BAPA) tahun 2012 dan nilai maksimum sebesar 31,26 atau sebesar Rp 37.761.220.693.695 termasuk kategori 
ukuran perusahaan besar karena memiliki total aset lebih dari Rp 100.000.000.000 yang dimiliki oleh PT. Lippo Karawaci Tbk. (LPKR) tahun 2014.

\section{Uji Asumsi Klasik}

Penelitian ini menggunakan beberapa tahap perhitungan, yaitu dengan menggunakan uji outlier yang dilakukan dengan skor standardized atau disebut $z$-score. Batasan $z$-score yang digunakan dalam penelitian ini adalah nilainya lebih besar dari 2,5 dan -2,5. Dalam penelitian ini terdapat 9 data yang harus di outlier, sehingga $\mathrm{N}$ dalam penelitian ini menjadi 93 sampel dari 102 data yang sudah terpilih menjadi sampel.

\section{Uji Normalitas}

Uji normalitas dilakukan untuk mengetahui apakah nilai residual dari model regresi terdistribusi secara normal atau tidak.

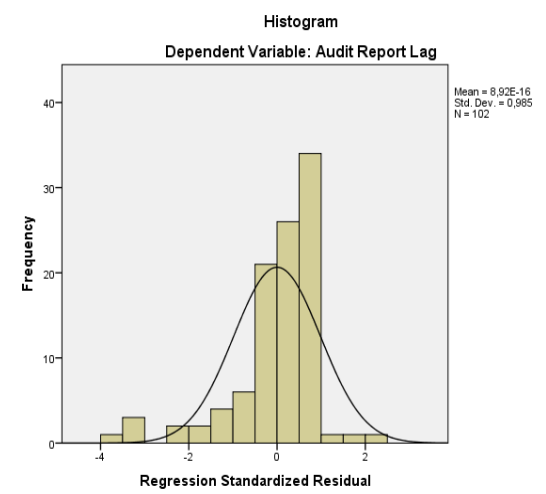

Sumber: Data yang diolah dari SPSS 21

\section{Gambar 1 Hasil Grafik Histogram Sebelum Outlier}

Berdasarkan gambar 1, menunjukkan pola tidak berdistribusi normal karena grafik tidak berbentuk seperti lonceng dan menceng ke kiri maupun ke kanan. Sehingga diperlukan proses outlier yang dilakukan dengan menggunakan nilai z-score.

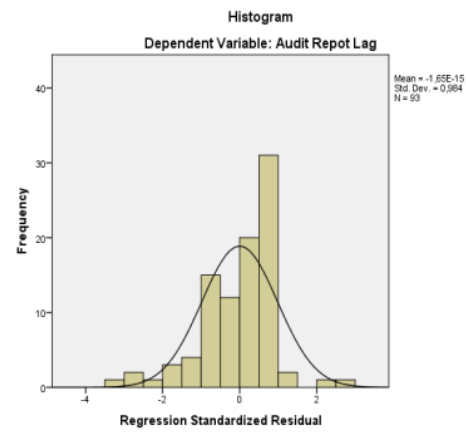

Sumber: Data yang diolah dari SPSS 21

\section{Gambar 2 Hasil Grafik Histogram Setelah Outlier}

Berdasarkan gambar 2, grafik histogram menunjukkan bahwa pola berdistribusi normal karena grafik berbentuk seperti lonceng dan tidak menceng ke kiri maupun ke kanan.Untuk menguji normalitas dapat juga menggunakan grafik normal propability plot sebagai berikut: 


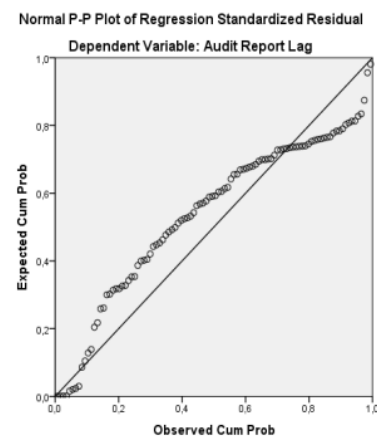

Sumber: Data yang diolah dari SPSS 21

\section{Gambar 3 Hasil Grafik Probability Plot Sebelum Outlier}

Berdasarkan gambar 3, grafik normal Probability Plot terlihat titik-titik tidak menyebar disekitar garis diagonal, serta penyebarannya tidak mengikuti arah garis diagonal, maka dapat disimpulkan bahwa model regresi ini tidak berdistribusi normal.

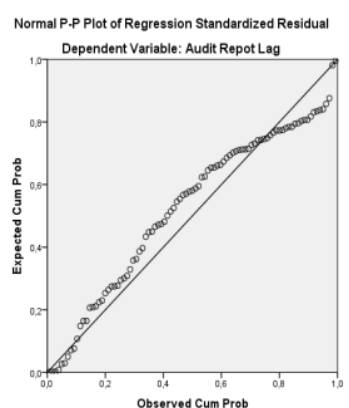

Sumber: Data yang diolah dari SPSS 21

\section{Gambar 4 Hasil Grafik Probability Plot Setelah Outlier}

Berdasarkan gambar 4, grafik normal probability plot terlihat titik-titik menyebar disekitar garis diagonal, serta

penyebarannya mengikuti arah garis diagonal, maka dapat disimpulkan bahwa model regresi ini berdistribusi normal. Selain menggunakan grafik histogram dan grafik probability plot menurut Ghozali (2013, hlm.164) dapat menggunakan uji statistik Kolmogorov-Smirnov. Jika nilai signifikansinya $>0,05$ data berdistribusi normal, namun jika nilai signifikansinya $<0,05$ data tidak berdistribusi normal. Berikut ini tabel hasil uji Kolmogorov-Smirnov sebelum outlier:

Tabel 3 Uji Kolmogorov-Smirnov Sebelum Outlier One-Sample Kolmogorov-Smirnov Test

\begin{tabular}{|c|c|c|c|c|c|}
\hline & & $\begin{array}{c}\text { Audit } \\
\text { Report Lag }\end{array}$ & Profitabilitas & Leverage & $\begin{array}{c}\text { Ukuran } \\
\text { Perusahaan }\end{array}$ \\
\hline \multirow[t]{2}{*}{$\mathrm{N}$} & & 102 & 102 & 102 & 102 \\
\hline & Mean & 77,64 & 7,3425 & 81,8535 & 28,8991 \\
\hline Normal Parameters ${ }^{\mathrm{a}, \mathrm{b}}$ & $\begin{array}{l}\text { Std. } \\
\text { Deviation }\end{array}$ & 9,831 & 5,43642 & 50,85668 & 1,20300 \\
\hline \multirow{3}{*}{$\begin{array}{l}\text { Most Extreme } \\
\text { Differences }\end{array}$} & Absolute &, 170 &, 146 & ,093 & ,066 \\
\hline & Positive & ,151 & ,146 & ,077 & ,042 \\
\hline & Negative &,- 170 &,- 101 &,- 093 &,- 066 \\
\hline Kolmogorov-Smirnov Z & & 1,719 & 1,480 & ,936 & 667 \\
\hline Asymp. Sig. (2-tailed) & &, 005 &, 025 & ,345 & ,765 \\
\hline
\end{tabular}

Sumber: Data sekunder yang telah diolah 
Berdasarkan tabel 3, diketahui bahwa nilai Asymp Sig (2-tailed) untuk variabel audit report lag dan profitabilitas nilai signifikansinya $<0,05$ artinya data tidak memenuhi uji normalitas. Sehingga

diperlukan proses outlier agar data dapat memenuhi uji normalitas. Berikut ini adalah tabel hasil uji Kolmogrov-Smirnov setelah Outlier:

Tabel 4 Uji Kolmogorov-Smirnov Setelah Outlier One-Sample Kolmogorov-Smirnov Test

\begin{tabular}{|c|c|c|c|c|c|}
\hline & & $\begin{array}{c}\text { Audit } \\
\text { Report Lag }\end{array}$ & Profitabilitas & Leverage & $\begin{array}{c}\text { Ukuran } \\
\text { Perusahaan }\end{array}$ \\
\hline $\mathrm{N}$ & & 93 & 93 & 93 & 93 \\
\hline & Mean & 78,94 & 6,7843 & 80,7199 & 28,9105 \\
\hline Normal Parameters ${ }^{\mathrm{a}, \mathrm{b}}$ & $\begin{array}{l}\text { Std. } \\
\text { Deviation }\end{array}$ & 7,526 & 4,35269 & 44,83575 & 1,19073 \\
\hline Most Extreme & Absolute & , 120 & ,119 & ,073 & ,056 \\
\hline Differences & Positive & , 120 & ,119 & ,073 &, 046 \\
\hline & Negative &,- 120 &,- 072 &,- 068 &,- 056 \\
\hline Asymp. Sig. (2-tailed) & & 1,102 & 1,152 &, 700 & $\begin{array}{l}, 536 \\
936\end{array}$ \\
\hline
\end{tabular}

Sumber: Data sekunder yang telah diolah

Berdasarkan tabel 4, dapat diketahui bahwa nilai Asymp Sig (2-tailed) untuk semua variabel dalam penelitian ini nilai signifikansinya $>0,05$ artinya data berdistribusi normal. Sehingga setelah dilakukan outlier agar dapat memenuhi uji asumsi klasik pada uji normalitas, $\mathrm{N}$ dalam penelitian ini menjadi 93 sampel dari 102 data yang sudah terpilih menjadi sampel.

\section{Uji Multikolinearitas}

Uji multikolinearitas digunakan untuk mengetahui apakah pada model regresi ditemukan adanya korelasi antar variabel independen. Berikut ini adalah tabel hasil uji multikolinearitas:

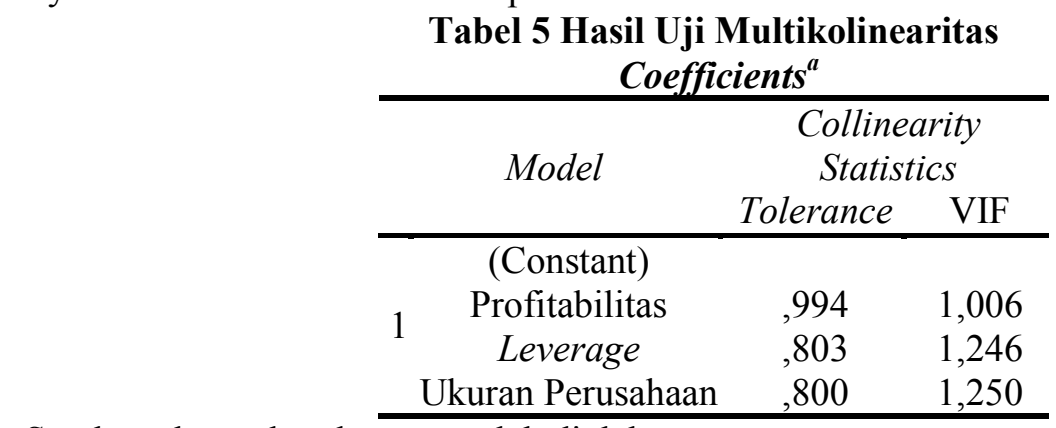

Sumber: data sekunder yang telah diolah

Berdasarkan tabel 5, diketahui bahwa seluruh variabel independen yaitu

profitabilitas, leverage dan ukuran perusahaan dalam model menunjukkan bahwa variabel independen memiliki angka Tolerance mendekati 1 berarti tidak ada korelasi antar variabel independen. Hasil perhitungan Variance Inflation Factor (VIF) juga menunjukkan hal yang sama variabel independen memiliki nilai VIF disekitar angka 1. Hal ini berarti bahwa seluruh variabel independen yang digunakan dalam penelitian ini tidak mengalami masalah multikolinearitas artinya antara variabel profitabilitas, leverage dan ukuran perusahaan tidak 
saling berhubungan. Masing-masing variabel dalam penelitian ini mengukur hal yang tidak terkait satu dengan lainnya.

\section{Uji Autokorelasi}

Dalam penelitian ini untuk menentukan ada tidaknya autokorelasi dengan uji DurbinWatson (DW), dengan ketentuan jika nilai DW di bawah -2 maka terjadi autokorelasi positif. Jika nilai DW berada di antara -2 dan +2 maka tidak terjadi autokorelasi. Nilai DW di atas +2 artinya terjadi autokorelasi negatif.

Tabel 6 Hasil Uji Autokorelasi
Model Summary

Sumber: data sekunder yang telah diolah

Berdasarkan tabel 6 di atas, dapat diketahui bahwa nilai Durbin Watson (DW) diperoleh sebesar 1,675. Angka DW berada diantara -2 dan +2 . Hal ini menunjukkan bahwa persamaan regresi dalam penelitian ini tidak terjadi autokorelasi. Hasil ini menunjukkan bahwa antara data tahun 2012, 2013, dan 2014 untuk variabel profitabilitas, leverage dan ukuran perusahaan tidak saling berhubungan.

\section{Uji Heteroskedastisitas}

Uji heteroskedastisitas bertujuan untuk mengetahui apakah dalam sebuah model regresi, terjadi ketidaksamaan variance dari residual satu pengamatan ke pengamatan yang lain.

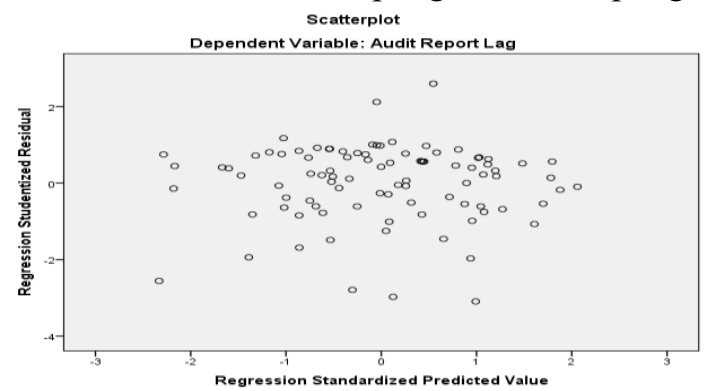

Sumber: Data yang diolah dari SPSS 21

\section{Gambar 5 Hasil Grafik Scatterplot Uji Heteroskedastisitas}

Berdasarkan gambar 5, diketahui bahwa hasil uji heteroskedastisitas dengan grafik scatterplot menunjukkan bahwa gambar titik-titik (point) menyebar secara acak dan tidak membuat pola tertentu serta tersebar di atas maupun di bawah angka 0 pada sumbu Y. Hal ini dapat disimpulkan bahwa tidak terjadi heteroskedastisitas pada model regresi.

\section{Uji Hipotesis}

Untuk menjawab hipotesis yang telah dibuat dapat digunakan metode uji f (simultan), analisis koefisien determinasi (adjusted $\mathrm{R}^{2}$ ), uji t (parsial), dan analisis regresi berganda.

\section{Uji F (Simultan)}

Uji $\mathrm{F}$ statistik digunakan untuk mengetahui apakah semua variabel independen yang dimasukan dalam model memepunyai pengaruh secara bersama-sama terhadap variabel dependen/terikat.

\begin{tabular}{lllll}
\multicolumn{4}{c}{ Tabel 7 Hasil Uji F (Simultan) } \\
ANOVA & & \\
\hline Model & $\begin{array}{c}\text { Sum of Df } \\
\text { Squares }\end{array}$ & Mean & Square & Fig. \\
& Squares & \\
\hline
\end{tabular}




\begin{tabular}{|c|c|c|}
\hline Regressio & 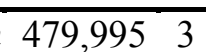 & 159,998 \\
\hline $\begin{array}{l}1 \text { Residual } \\
\text { Total }\end{array}$ & $\begin{array}{l}4731,61889 \\
5211,61392\end{array}$ & 53,164 \\
\hline
\end{tabular}

Sumber: data sekunder yang telah diolah

Berdasarkan tabel 7, hasil uji ANOVA (Analysis of Variance) atau uji F, menunjukkan bahwa nilai $F_{\text {hitung }}$ sebesar 3,010 dengan tingkat signifikansi 0,034. Dengan taraf signifikansi sebesar 0,05 dimana df1 (k-1) yaitu 3-1=2, dan df2 (n-k-1) yaitu 93-3-1 = 89. $(n=$ jumlah sampel, $\mathrm{k}=$ jumlah variabel)

Sehingga diperoleh $\mathrm{F}_{\text {tabel }}$ sebesar 2,71, karena nilai $\mathrm{F}_{\text {hitung }}>\mathrm{F}_{\text {tabel }}$ yaitu 3,010 $>2,71$ dengan tingkat signifikansi 0,034 atau lebih kecil dari taraf yang ditentukan 0,05. Dengan demikian bahwa $\mathrm{H}_{0}$ ditolak dan $\mathrm{H}_{\mathrm{a}}$ diterima, sehingga dapat disimpulkan bahwa profitabilitas, leverage dan ukuran perusahaan secara bersama-sama mempunyai pengaruh yang signifikan terhadap audit report lag.

\section{Uji Adjusted R ${ }^{2}$}

Koefisien determinasi digunakan untuk mengukur seberapa jauh kemampuan model dalam menerangkan variasi variabel dependen.

\begin{tabular}{cc}
$\begin{array}{c}\text { Tabel } 8 \text { Hasil Uji } \\
\text { Model Summary }\end{array}$ \\
\hline Model & Adjusted $R$ Square \\
\hline 1 &, 061 \\
\hline
\end{tabular}

Sumber: data sekunder yang telah diolah

Berdasarkan tabel 8, diketahui bahwa nilai koefisien determinasi dari Adjusted $\mathrm{R}^{2}$ adalah sebesar 0,061 . Hal ini menunjukkan bahwa 6,1\% dari variabel audit report lag dapat dijelaskan atau dipengaruhi oleh variabel profitabilitas, leverage dan ukuran perusahaan. Sedangkan sisanya sebesar 93,9\% dijelaskan atau dipengaruhi oleh variabel-variabel lain di luar penelitian ini seperti ukuran KAP, jenis industri, umur perusahaan, dan opini audit.

\section{Uji t (Parsial)}

Uji t (parsial) menunjukkan seberapa jauh pengaruh variabel independen secara individual dalam menerangkan variasi variabel dependen.

Tabel 9 Hasil Uji t (Parsial)

Coefficients $^{a}$

\begin{tabular}{llcc}
\hline & Model & $\mathrm{t}$ & Sig. \\
& & & \\
\hline \multirow{4}{*}{1} & (Constant) & 5,606 &, 000 \\
& Profitabilitas & $-2,324$ &, 022 \\
& Leverage &,- 186 &, 853 \\
& Ukuran Perusahaan & $-1,456$ &, 149 \\
\hline
\end{tabular}

Sumber: data sekunder yang telah diolah

Berdasarkan output tabel 9 di atas adalah sebagai berikut:

a. Profitabilitas

Profitabilitas memiliki nilai $t_{\text {hitung }}$ sebesar $-2,324$ dan $t_{\text {tabel }}$ sebesar 1,66216, sehingga $\mathrm{t}_{\text {hitung }}>\mathrm{t}_{\text {tabel }}$ dengan signifikansi untuk variabel profitabilitas sebesar 0,022 yang nilainya lebih rendah dari tingkat signifikansi yaitu 0,05 . Maka diperoleh $\mathrm{H}_{0}$ ditolak dan $\mathrm{H}_{\mathrm{a}}$ diterima, sehingga dapat disimpulkan bahwa profitabilitas berpengaruh signifikan terhadap audit report lag.

b. Leverage 
Leverage memiliki nilai $t_{\text {hitung }}$ sebesar $-0,186$ dan $t_{\text {tabel }} 1,66216$, sehingga $t_{\text {hitung }}<t_{\text {tabel }}$ dengan signifikansi untuk variabel leverage sebesar 0,853 yang nilainya lebih besar dari tingkat signifikansi yaitu 0,05 . Maka diperoleh $\mathrm{H}_{0}$ diterima dan $\mathrm{H}_{\mathrm{a}}$ ditolak, sehingga dapat disimpulkan bahwa leverage tidak berpengaruh signifikan terhadap audit report lag.

c. Ukuran Perusahaan

Ukuran perusahaan memiliki nilai $t_{\text {hitung }}$ sebesar $-1,456$ dan $t_{\text {tabel }} 1,66216$, sehingga $\mathrm{t}_{\text {hitung }}<\mathrm{t}_{\text {tabel }}$ dengan signifikansi untuk variabel ukuran perusahaan sebesar 0,149 yang nilainya lebih besar dari tingkat signifikansi yaitu 0,05 . Maka diperoleh $\mathrm{H}_{0}$ diterima dan $\mathrm{H}_{\mathrm{a}}$ ditolak, sehingga dapat disimpulkan bahwa ukuran perusahaan tidak berpengaruh signifikan terhadap audit report lag.

\section{Model Regresi Berganda}

Analisis regresi linier berganda yaitu metode statistik yang umum digunakan untuk meneliti hubungan antara sebuah variabel dependen dengan beberapa variabel independen. Berikut ini tabel hasil analisis regresi berganda yang telah dilakukan dengan SPSS 21:

\begin{tabular}{|c|c|c|}
\hline \multicolumn{3}{|c|}{$\begin{array}{c}\text { Tabel } 10 \text { Hasil Analisis Regresi Berganda } \\
\text { Coefficients }^{\mathrm{a}}\end{array}$} \\
\hline \multirow{2}{*}{ Model } & \multicolumn{2}{|c|}{ Unstandardized Coefficient } \\
\hline & $\mathrm{B}$ & Std. Error \\
\hline (Constant) & 112,029 & 19,983 \\
\hline Profitabilitas &,- 407 &, 175 \\
\hline Leverage &,- 004 & 019 \\
\hline Ukuran Perusahaan & $-1,039$ &, 714 \\
\hline
\end{tabular}

Sumber: data sekunder yang telah diolah

Berdasarkan tabel 10 di atas, maka dapat diperoleh persamaan regresi sebagai berikut:

$$
\begin{aligned}
& \text { Keterangan : } \\
& \text { ARL = Audit Report Lag } \\
& \text { PROF }=\text { Profitabilitas } \\
& \text { LEV = Leverage } \\
& \text { UP = Ukuran Perusahaan }
\end{aligned}
$$

$$
A R L=112,029-0,407 \text { PROF }-0,004 \mathrm{LEV}-1,039 \mathrm{UP}
$$

Dari persamaan tersebut, dapat diketahui bahwa konstanta sebesar 112,029 menjelaskan jika profitabilitas, leverage dan ukuran perusahaan bernilai konstan (0) maka audit report lag selama 112 hari.

Profitabilitas memiliki koefisien regresi sebesar $-0,407$ artinya jika profitabilitas mengalami kenaikan 1\%, maka audit report lag akan mengalami penurunan 0,407 hari dengan asumsi bahwa variabel independen lainnya bernilai tetap.

Leverage memiliki koefisien regresi sebesar $-0,004$ artinya jika leverage mengalami kenaikan 1\%, audit report lag akan mengalami penurunan sebesar 0,004 hari dengan asumsi bahwa variabel independen lainnya bernilai tetap.

Ukuran perusahaan memiliki koefisien regresi sebesar -1,039 artinya jika ukuran perusahaan mengalami kenaikan 1\%, maka audit report lag akan mengalami penurunan 1,039 hari dengan asumsi bahwa variabel independen lainnya bernilai tetap. 


\subsection{Pembahasan}

Hasil uji hipotesis pertama dalam penelitian ini menunjukkan bahwa profitabilitas secara parsial (uji t) yang diukur menggunakan Return on Asset (ROA) memiliki $t_{\text {hitung }}-2,324>t_{\text {tabel }}$ 1,66216 dengan tingkat signifikansi $0,022<0,05$. Dengan demikian diperoleh $\mathrm{H}_{0}$ ditolak dan $\mathrm{H}_{\mathrm{a}}$ diterima, sehingga dapat disimpulkan bahwa profitabilitas berpengaruh signifikan terhadap audit report lag. Hal ini menunjukkan bahwa perusahaan yang mengalami kerugian, audit report lag perusahaan tersebut akan lebih panjang/lama. Karena auditor akan lebih berhati-hati selama proses audit jika percaya bahwa profitabilitas yang rendah atau kerugian mungkin disebabkan karena kegagalan keuangan perusahaan dan kecurangan manajemen informasi tentang laba, dimana auditor akan menyampaikan bad news kepada investor dan pihak-pihak lainnya. Sebaliknya jika perusahaan mengalami keuntungan, audit report lag akan lebih pendek/cepat, sehingga good news tersebut dapat segera disampaikan kepada investor dan pihak-pihak lainnya. Hasil penelitian ini sesuai dengan teori dari Carslaw \& Kaplan dalam Hersugondo \& Kartika (2013). Hal ini juga didukung oleh penelitian Lianto \& Kusuma (2010), Ariyani \& Budiarha (2014), serta Vuko \& Cular (2014). Namun hasil penelitian ini tidak konsisten dengan penelitian Modugu et.al (2012), Angruningrum \& Wirakusuma (2013), serta Togasima \& Christiawan (2014).

Hasil uji hipotesis kedua dalam penelitian ini menunjukkan bahwa leverage secara parsial (uji t) yang diukur menggunakan Debt to Equity Ratio (DER) memiliki $\mathrm{t}_{\text {hitung }}-0,186<\mathrm{t}_{\text {tabel }}$ 1,66216 dengan tingkat signifikansi 0,853 $>0,05$. Dengan demikian diperoleh $\mathrm{H}_{0}$ diterima dan $\mathrm{H}_{\mathrm{a}}$ ditolak, sehingga dapat disimpulkan bahwa leverage tidak berpengaruh signifikan terhadap audit report lag. Berdasarkan data perusahaan yang dijadikan sampel pada penelitian ini menunjukkan bahwa tingkat leverage sebagian besar dalam penelitian ini memiliki leverage tinggi yaitu sebesar $80,72 \%$. Namun, sebagian besar audit report lag perusahaan pada penelitian sebesar 79 hari, artinya audit report lag pada sampel yang digunakan dalam penelitian ini termasuk cepat karena audit report lag tidak lebih dari 90 hari. Hal ini menunjukkan bahwa tinggi dan rendahnya leverage tidak mempengaruhi audit report lag perusahaan. Hasil penelitian ini sesuai dengan penelitian Modugu et.al (2012), Pourali et.al (2013), Anggradewi \& Haryanto (2014), serta Togasima \& Christiawan (2014). Namun hasil penelitian ini tidak konsisten dengan penelitian Lianto \& Kusuma (2010), Febrianty (2011), Puspitasari \& Sari (2012), Angruningrum \& Wirakusuma (2013), Hersugondo \& Kartika (2013), serta Vuko \& Cular (2014).

Hasil uji hipotesis ketiga dalam penelitian ini menunjukkan bahwa ukuran perusahaan secara parsial (uji $t$ ) yang diukur menggunakan total aset memiliki $t_{\text {hitung }}-1,456<t_{\text {tabel }} 1,66216$ dengan tingkat signifikansi $0,149>0,05$. Dengan demikian diperoleh $\mathrm{H}_{0}$ diterima dan $\mathrm{H}_{\mathrm{a}}$ ditolak, sehingga dapat disimpulkan bahwa ukuran perusahaaan tidak berpengaruh signifikan terhadap audit report lag. Berdasarkan data perusahaan yang dijadikan sampel pada penelitian ini menunjukkan bahwa sebagian besar sampel perusahaan sub sektor property dan real estate memiliki kategori ukuran perusahaan besar yaitu memiliki total aset lebih dari Rp 100.000.000.000 (seratus miliar rupiah). Sementara sebagian besar audit report lag dari sampel ini memiliki audit report lag yang panjang. Hal ini menunjukkan bahwa ukuran perusahaan tidak berpengaruh terhadap audit report lag. Hasil penelitian ini sesuai dengan penelitian Lianto \& Kusuma (2010) dan Anggradewi \& Haryanto (2014). Namun hasil penelitian ini tidak konsisten dengan penelitian Febrianty (2011), Modugu et.al (2012), Puspitasari \& Sari (2012), Hersugondo \& Kartika (2013), Pourali et.al (2013), Ariyani \& Budiartha (2014), Togasima \& Christiawan (2014), serta Vuko \& Cular (2014).

\section{SIMPULAN DAN KETERBATASAN}

\subsection{Simpulan}

Berdasarkan hasil penelitian dan pembahasan yang telah diuraikan, maka dapat diambil kesimpulan sebagai berikut:

a. Profitabilitas berpengaruh signifikan terhadap audit report lag.

b. Leverage tidak berpengaruh signifikan terhadap audit report lag. 
c. Ukuran perusahaan tidak berpengaruh signifikan terhadap audit report lag.

\subsection{Keterbatasan}

Penelitian ini memiliki keterbatasan yang dapat mempengaruhi hasilnya, keterbatasan dari penelitian ini adalah sebagai berikut:

a. Terdapat perusahaan yang tidak menerbitkan laporan keuangan yang telah diaudit dan dipublikasikan secara berturut-turut di Bursa Efek Indonesia (BEI) periode tahun 20122014.

b. Terdapat perusahaan yang mengalami kerugian selama periode tahun 2012-2014.

\section{DAFTAR PUSTAKA}

Anggradewi, AM \& Haryanto (2014), Analisis faktor-faktor yang mempengaruhi audit delay, Diponegoro Journal of Accounting, vol.3, no.2, hlm. 1-10

Angruningrum, S \& Wirakusuma, MG (2013), Pengaruh profitabilitas, leverage, kompleksitas operasi, reputasi KAP dan komite audit pada audit delay, E-Jurnal Akuntansi Universitas Udayana, vol.5, no.2, hlm. 251-270

Arens, AA, Elder, RJ \& Beasley, MS (2008), Auditing dan jasa assurance, Erlangga, Jakarta.

Ariyani, NNTD \& Budiarta, IK (2014), Pengaruh profitabilitas, ukuran perusahaan, kompleksitas operasi perusahaan dan reputasi KAP terhadap audit report lag pada perusahaan manufaktur, E-Jurnal Akuntansi Universitas Udayana, vol.8, no.2, hlm. 217230

Febrianty (2011), Faktor-faktor yang berpengaruh terhadap audit delay perusahaan perdagangan yang terdaftar di BEI periode 2007-2009, Jurnal Ekonomi dan Informasi Akuntansi (JENIUS), vol.1, no.3, September 2012, hlm. 294-320

Ghozali, Imam (2013), Aplikasi analisis multivariate dengan program IBM SPSS 21 update PLS regresi, Badan Penerbit Universitas Diponegoro, Semarang.

Harahap, Sofyan Safri (2013), Analisis kritis atas laporan keuangan, Rajawali Pers, Jakarta.

Harahap, Sofyan Safri (2011), Teori akuntansi edisi revisi 2011, Rajawali Pers, Jakarta.

Hersugondo \& Kartika, A (2013), Prediksi probabilitas audit delay dan faktor determinannya, Jurnal Ekonomi-Manajemen-Akuntansi, no.35, Oktober 2013, hlm. 1-21

Indonesia, Keputusan Ketua BAPEPAM: KEP-346/BL/2011, tentang penyampaian laporan keuangan berkala emiten atau perusahaan publik, 2012, Jakarta.

Indonesia, Keputusan Ketua BAPEPAM: KEP-431/BL/2012, tentang penyampaian laporan keuangan berkala emiten atau perusahaan publik, 2012, Jakarta.

Indonesia, Undang-Undang Republik Indonesia Nomor 21 Tahun 2011 tentang penggantian nama BAPEPAM menjadi OJK, Otoritas Jasa Keuangan, diakses 1 September 2015, www.ojk.go.id/siaran-pers-kinerja-otoritas-jasa-keuangan-triwulan-i-2014 
Lianto, N \& Kusuma, BH (2010), Faktor-faktor yang berpengaruh terhadap audit report lag, Jurnal Bisnis dan Akuntansi, vol.12, no.2, Agustus 2010, hlm. 97-106

Lembaga Penelitian dan Pemberdayaan Masyarakat Universitas Pembangunan Nasional "Veteran" Jakarta (2014), Pedoman penulisan karya ilmiah bagi dosen dan mahasiswa, diakses 15 September 2015,

http://library.upnvj.ac.id/index.php?p=show_detail\&id=5705

Modugu, PK, Eragbhe, E \& Ikhatua, J (2012), Determinants of audit delay in Nigerian companies: empirical evidence, Research Journal of Finance and Accounting, vol.3, no.6, p. 2222-2847

Pourali, MR, Jozi, M, Rostami, KH, Taherpour, GR \& Niazi, F (2013), 'Investigation of effective factors in audit delay: evidence from Tehran Stock Exchange (TSE)', Reasearch Journal of Applied Sciences, Engineering and Technology, vol.5, no.2, p. 405-410

Puspitasari, E \& Sari, AN (2012), 'Pengaruh karakteristik perusahaan terhadap lamanya waktu penyelesaian audit (audit delay) pada perusahaan manufaktur yang terdaftar di Bursa Efek Indonesia', Jurnal Akuntansi dan Auditing, vol.9, no.1, November 2012, hlm. 1-96

Santoso, Singgih (2014), Panduan lengkap spss versi 20 edisi revisi, Gramedia, Jakarta.

Santoso, Singgih (2010), Statistik parametrik: konsep dan aplikasi dengan spss, Gramedia, Jakarta.

Sudana, IM (2011), Manajemen keuangan perusahaan teori dan praktik, Erlangga, Jakarta.

Togasima, CN \& Christiawan, YJ (2014), Analisis faktor-faktor yang mempengaruhi audit report lag pada perusahaan yang terdaftar di Bursa Efek Indonesia pada tahun 2012, Business Accounting Review, vol.2, no.2, Juli 2014, hlm. 151-159

Vuko, T \& Cular, M (2014), Finding determinants of audit delay by pooled OLS regression analysis, Croatian Operational Research Review (CRORR), vol.5, p. 81-91 